\title{
Spatial and temporal fishing patterns at the outer banks of the Southern California Bight
}

\author{
Daniel J. Pondella II ${ }^{1}{ }^{*}$, Matthew J. Robart ${ }^{1}$, Jeremy T. Claisse ${ }^{1,2}$, Jonathan P. Williams ${ }^{1}$, \\ Chelsea M. Williams ${ }^{1}$, Amanda J. Zellmer ${ }^{1}$, and Susan E. Piacenza ${ }^{1,3}$ \\ ${ }^{1}$ Vantuna Research Group, Occidental College, 1600 Campus Road, Los Angeles, CA 90041 \\ ${ }^{2}$ Department of Biological Sciences, California State Polytechnic University, Pomona, \\ 3801 W. Temple Ave., Pomona, CA 91768 \\ ${ }^{3}$ Present address: Department of Biology, University of West Florida, \\ 11000 University Parkway, Pensacola, FL 32514
}

\begin{abstract}
We analyzed recreational and commercial catch records from 1980 to 2009 for the fishing blocks associated with the 5 southern offshore banks of the Southern California Bight (Cortes Bank, Tanner Bank, Northeast Bank, Cherry Ridge, and Garrett Ridge). Recreational fishers and divers targeted pelagic taxa (e.g., tunas and Yellowtail) but instead landed more benthic taxa (e.g., rockfishes, Ocean Whitefish, and California Sheephead). For the commercial fisheries, pelagics (Bluefin Tuna, Albacore, Skipjack, Yellowfin Tuna, Pacific Bonito, and Swordfish) were the most important taxa and represented a significant proportion (8\%-27\%) of the landings of these fishes in the bight. These fishes were caught primarily at Cortes and Tanner Banks, which together only represent $3.7 \%$ of the fishing grounds in the region. In addition, this proportion of catch of these critical species has been significantly increasing at the outer banks during this period. Based on their geography and physical oceanography, we propose that these offshore banks comprise a unique habitat for pelagic resources in the Southern California Bight.
\end{abstract}

Resumen.-Analizamos los registros de pesca comercial y deportiva, desde el año 1980 al 2009, de los bloques de pesca asociados a las cinco riberas marítimas del sur de la bahía del sur de California (Ribera Cortes, Ribera Tanner, Ribera del noreste, Cherry Ridge, y Garrett Ridge). El blanco de los pescadores y de los buzos deportivos fueron los taxa pelágicos (e.g., atunes y cola amarilla), aunque se encontraron más taxa bentónicos (e.g., lubina rayada atlántica, blanquillo fino y vieja de California). Para los pescadores comerciales, los taxa pelágicos (atún azul, atún blanco, listado, atún de aleta amarilla, bonito del pacífico oriental, y pez espada) resultaron de mayor importancia y representaron una proporción significativa (8\%-27\%) de sus pescas en la bahía. Estos peces fueron capturados principalmente en las riberas Cortes y Tanner, que representan solamente 3.7\% de las zonas de pesca de la región. Además, el porcentaje de captura de estas especies clave se incrementó significativamente en las afueras de los bloques durante este período. Basándonos en su geografía y en su oceanografía física, creemos que estos bancos marítimos constituyen un hábitat singular para los recursos pelágicos de la Bahía del Sur de California.

Along the outer reaches of the Southern California Bight (SCB) are 5 offshore banks and seamounts (Cortes Bank, Tanner Bank, Northeast Bank, Cherry Ridge, and Garrett Ridge; Fig. 1). Due to a variety of physical oceanographic and geologic properties, these features are distinctive in the region. The tops of these offshore banks are most similar to island habitats without the emergent land masses (Emery 1960). For example, Cortes Bank has 1359.6 ha and Tanner Bank has 63.2 ha of shallow subtidal $(<30 \mathrm{~m})$ reef habitat. Cortes Bank ranks sixth after Santa Rosa
(9087.5 ha), San Nicolas (5249.9 ha), Santa Cruz (4837.7 ha), San Clemente (3593.2 ha), and San Miguel (3461.8 ha) Islands for shallow water reef habitat among the Channel Islands, representing $\sim 4.53 \%$ of offshore reefs in the SCB (Pondella et al. 2015). The 3 other prominent, relatively shallow features are Cherry Bank (28 m), Garrett Ridge (39 m), and Northeast Bank (108 m). Surrounding these ridges and banks are basins and canyons (San Nicolas, East Cortes, West Cortes, and Tanner). The basins have sill depths from $1100 \mathrm{~m}$ to $1400 \mathrm{~m}$ and basin depths to $1979 \mathrm{~m}$ (Emery 1960).

*Corresponding author: pondella@oxy.edu 


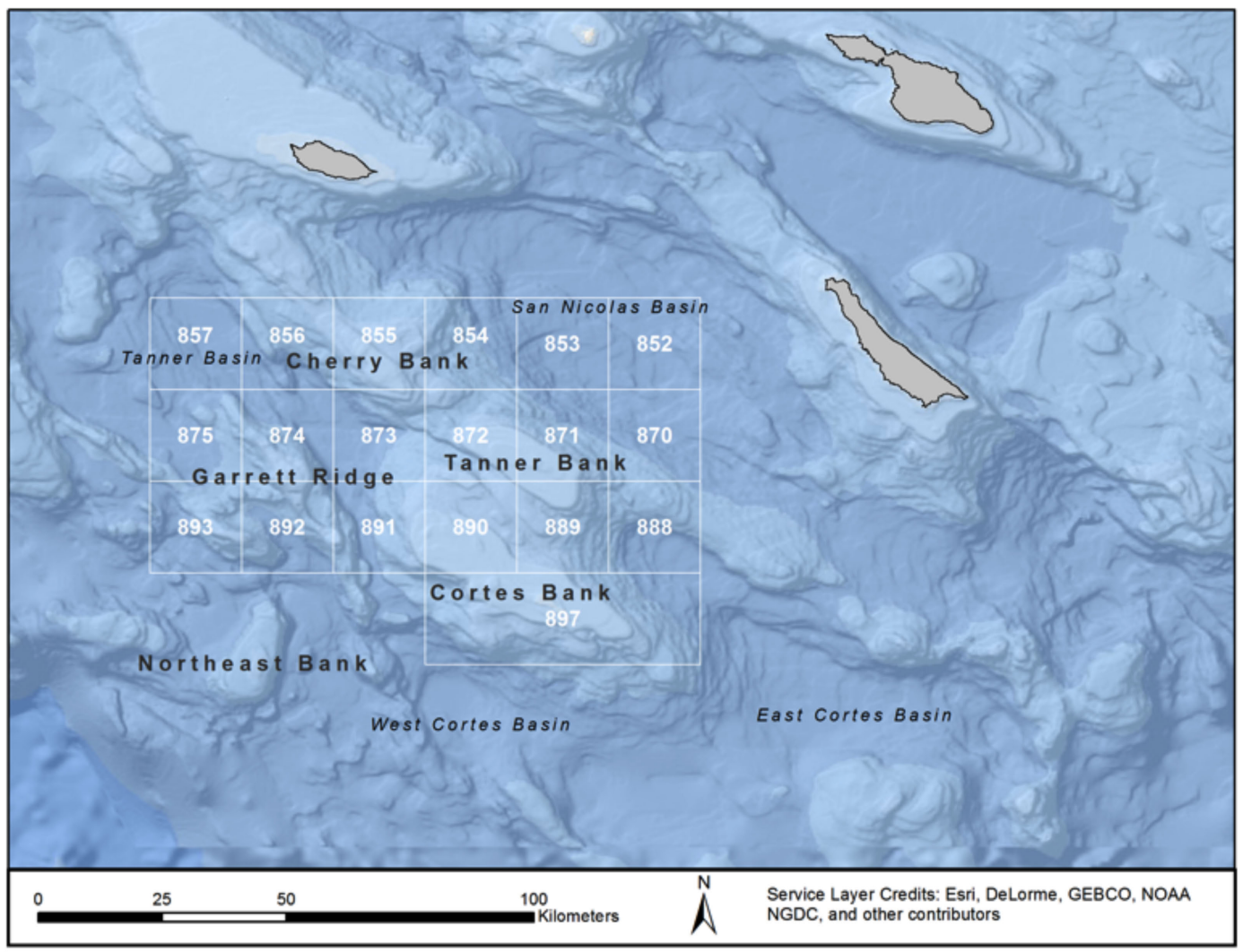

Fig. 1. Bathymetric map including the offshore banks of the Southern California Bight with an overlay of the fishing blocks analyzed in this study.

This region, referred to in the geological literature as the California Continental Borderlands, lies at the southern edge of the SCB, which is floored by a $\sim 300-\mathrm{km}$-wide region of extensively faulted and extended continental crust comprising Mesozoic metamorphic and intrusive igneous rock, as well as Neogene sedimentary and volcanic units (Crouch and Suppe 1993). It differs markedly from the continental shelf north of Point Conception, the northern border of the SCB, which is typically $<100 \mathrm{~km}$ wide. Seismic evidence (Lekic et al. 2011) shows that the entire thickness of the Pacific Plate (i.e., the continental crust plus the uppermost mantle) has been extended and thinned. Differential subsidence along the many faults that cut the California Continental Borderlands has produced the distinctive topography of islands and outer banks separated by 1-km-deep basins. Thus, these banks and ridges lie on the outer edge of an atypical section of the continental shelf further offshore than any other similar feature in California and provide a variety of marine habitats because of their stark bathymetry.

Oceanographically, the SCB occurs within the broader context of the California Current, which is a major equatorward alongshore current flowing along the eastern boundary of the North Pacific Ocean. The circulation is driven by basin-scale forcing and is amplified along the coast by the formation of an equatorward jet due to coastal upwelling (Auad et al. 2011). This coastal upwelling of deep, cold, nutrient-rich water subsidizes primary productivity in the form of phytoplankton and benthic macrophytes, thus allowing rich biological communities to flourish both offshore and directly along the coastline of the U.S. West Coast and along the west coast of Mexico's Baja California. The geographic configuration of the SCB results in the formation of a large counter-clockwise eddy landward of the main equatorward flow (Hickey 1992), 
generally described as a poleward surface inshore countercurrent along the coast and a poleward undercurrent (California Undercurrent) that flows northward at a depth of approximately $200 \mathrm{~m}$ along the continental slope (Dong et al. 2009). Temporal and mesoscale spatial variability due to seasonal changes and local wind forcing result in the weakening and even reversal of the inshore countercurrent during spring upwelling season, yet strengthen poleward flow during summer and into fall (Bray et al. 1999). This circulation pattern coupled with the complex bathymetry of the SCB results in strong abiotic gradients within the SCB. The shallow offshore banks in the southwest portion of the SCB are exposed to the main offshore portion of the equatorward-flowing California Current as well as the poleward-flowing California Undercurrent, depending on depth. When currents interact with the steep and complex bathymetry of seamounts and banks, increased vertical mixing results in turbulent upwelling that brings nutrient-rich deep water near the surface where it boosts both pelagic and benthic communities.

Because of the geological and oceanographic intricacies of this region, the SCB represents a transitional zone between the warm temperate San Diegan fauna and the cool temperate Oregonian fauna, dramatically increasing the overall diversity in the region (Allen and Horn 1978, Pondella et al. 2005). These biogeographic regions are generally described in 2-dimensional space throughout the SCB. Due to the range in depth and location with respect to the California Current, however, the offshore banks support warm water taxa in their extensive shallow reaches and cool water taxa at depth. Layering on the pelagic faunal components creates a vibrant, diverse, and productive ecosystem that is not replicated anywhere else in the region, the state, or the Pacific Northwest (Genin and Boehlert 1985). Furthermore, the considerable distance from the mainland and inhabited islands has provided this area with a partial refuge from the intense commercial and recreational harvest of marine organisms that occurs at shallow water reefs along the mainland and the Channel Islands.

Fish surveys were conducted at Tanner and Cortes Banks between 1997 and 2002 using the manned research submersible Delta to examine rockfish populations (Yoklavich et al. 2007, Love et al. 2009). Yoklavich et al. (2007) found that Tanner and Cortes Banks were the hot spot in terms of total abundance and biomass of Cowcod (Sebastes levis) among the major offshore rock banks they surveyed. Cowcod were previously declared as overfished by the National Marine Fisheries Service of the National Oceanic and Atmospheric Administration and estimated to be at $7 \%$ of their unfished biomass (Butler et al. 2003). Tanner and Cortes Banks represent important habitat in the SCB for this and other important commercial rockfish species.

The outer banks have long supported valuable economic interests because of their high productivity and access to various habitats. These banks form a potentially strong link between habitat conservation and health of productive and sustainable fisheries. California's ocean economy is the largest in the United States with a total gross state product of 21.4 billion USD in 2000 (Kildow and Colgan 2005). While this economy is strong, there have been marked declines in the fishing industry, and nearly half of its landings by weight are from Southern California (Kildow and Colgan 2005). The offshore banks are also extensively used by scuba charters, commercial passenger fishing vessels (CPFV), commercial fishers, recreational fishers, divers, and most recently surf charters. Considering the curve of the Southern California coastline, the relatively uniform distance to these banks from ports throughout the SCB creates numerous access points for high-value overnight excursions for similar prices (Pendleton and Rooke 2006). As an example of the economic importance of fishing in the region, total expenditures for charter and private boats alone in Southern California have been estimated to average almost 400 million USD annually (Gautam et al. 1996), with a significant amount of this effort focused on the offshore banks.

Considering these factors, we analyzed 29 years (1980-2009, omitting 1985) of spatially explicit commercial and recreational landings data from the SCB (Perry et al. 2010, Zellmer et al. 2018) and examined the hypothesis that the dynamic and productive nature of these seamounts and banks disproportionately supports pelagic fisheries, especially commercial fisheries. 


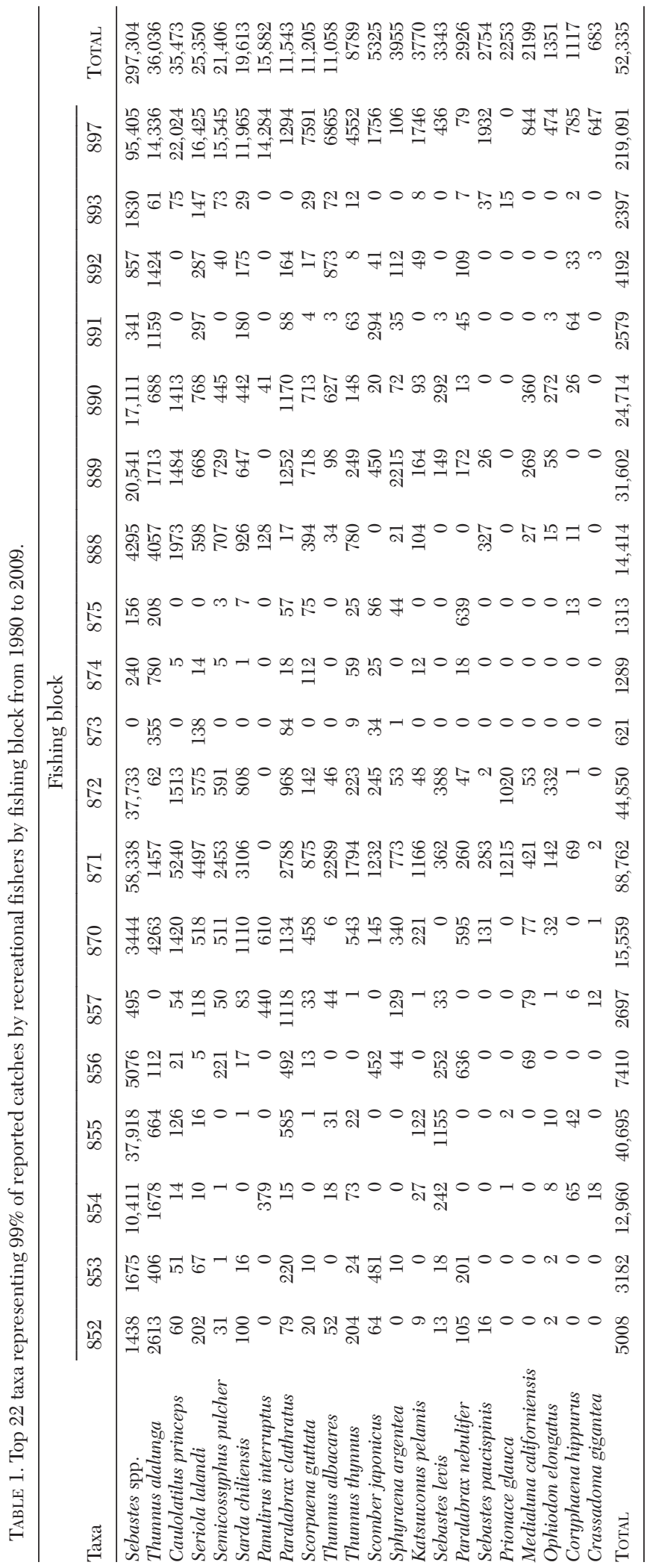



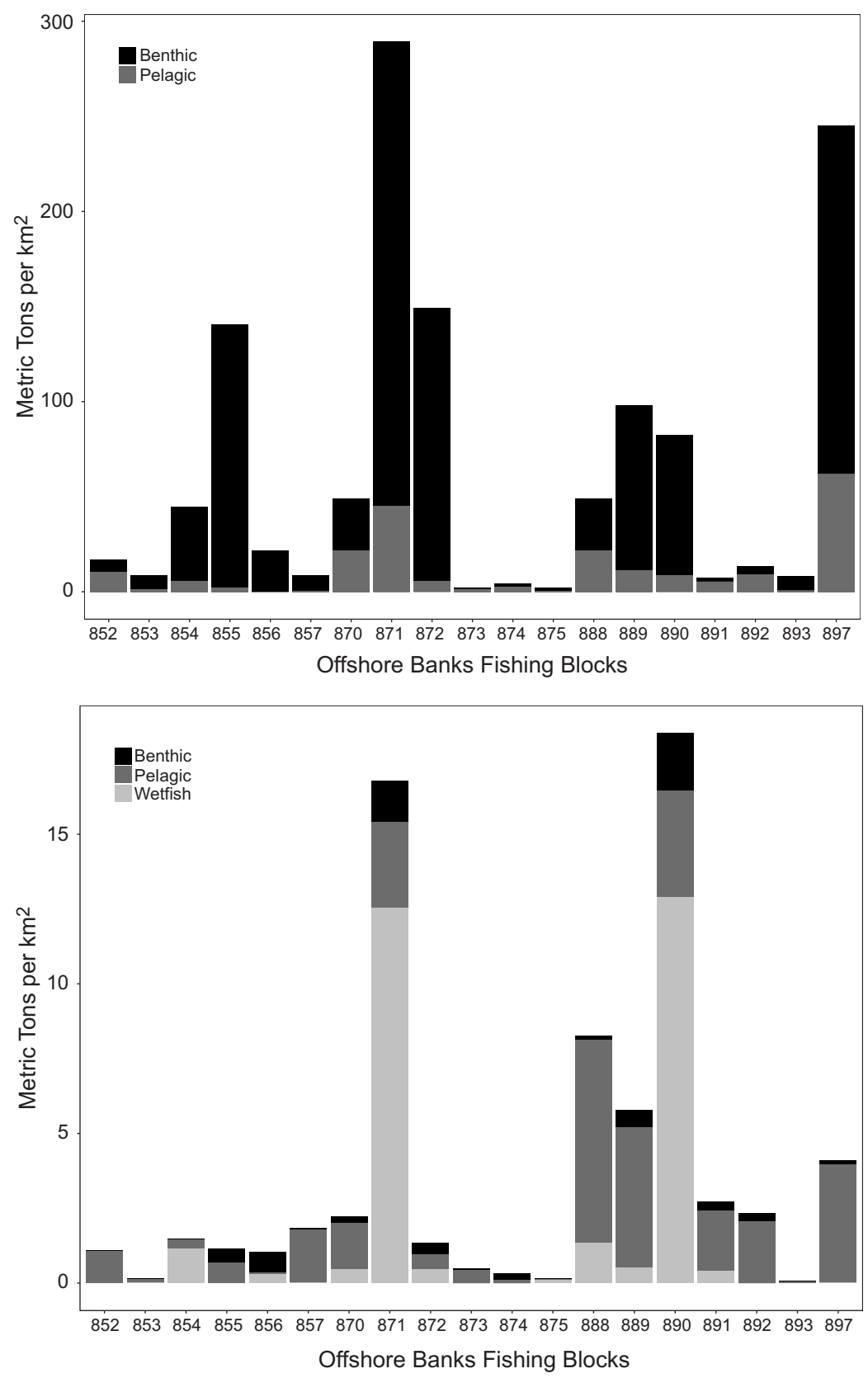

Fig. 2. Top 10 species caught by recreational fishers (top) and commercial fishers (bottom), grouped by associated habitat for each fishing block. Refer to Table 2 for ranks and species included in each group.

\section{Methods}

Commercial and recreational fishing records were downloaded from the Pacific Coast Fisheries GIS Resource Database (Perry et al. 2010). The commercial fisheries data come from monthly tabulations of landing receipts collected by the California Department of Fish and Wildlife between 1972 and 2009 (Perry et al. 2010). The recreational fisheries data cover monthly harvests between 1980 and 2009 recorded in CPFV logbooks (Hill and Schneider 1999, Perry et al. 2010). We limited the data set to the years 1980-2009 
TABLE 2. Top 10 taxa reported in recreational and commercial catches at offshore banks fishing blocks from 1980 to 2009 , with habitat association group. MT = metric ton.

\begin{tabular}{clrl}
\hline Rank & Recreational catch & $\begin{array}{c}\text { Individuals } \\
\text { per km² }\end{array}$ & Group \\
\hline 1 & Rockfish spp. & 846.87 & Benthic \\
2 & Albacore Tuna & 91.63 & Pelagic \\
3 & Ocean Whitefish & 71.89 & Benthic \\
4 & Yellowtail & 49.80 & Pelagic \\
5 & Pacific Bonito & 40.24 & Pelagic \\
6 & California Sheephead & 38.17 & Benthic \\
7 & Kelp Bass & 37.00 & Benthic \\
8 & Yellowfin Tuna & 22.41 & Pelagic \\
9 & California Spiny Lobster & 21.97 & Benthic \\
10 & California Scorpionfish & 19.91 & Benthic \\
\hline Rank & Commercial catch & MT per km² & Group \\
\hline 1 & Mackerel spp. & 28.8898 & Wetfish \\
2 & Bluefin Tuna & 8.9006 & Pelagic \\
3 & Albacore Tuna & 7.2417 & Pelagic \\
4 & Rockfish spp. & 5.8947 & Benthic \\
5 & Pacific Bonito & 5.7968 & Pelagic \\
6 & Skipjack Tuna & 4.9031 & Pelagic \\
7 & Yellowfin Tuna & 3.7839 & Pelagic \\
8 & Swordfish & 2.0075 & Pelagic \\
9 & Northern Anchovy & 1.4873 & Wetfish \\
10 & Thresher Shark & 1.3753 & Pelagic \\
\hline & & &
\end{tabular}

because CPFV data were only reported back to 1980 in the data set. Commercial and recreational data from 1985 were removed because no spatially explicit recreational data were available for that year. The data are all recorded in the California Department of Fish and Wildlife reporting blocks (blocks 643-916, excluding block 650), allowing us to spatially assign catch to the outer banks region (blocks 852-857, 870-875, 888-893, and 897) versus the remaining areas of the SCB. For each species, we tabulated the amount of harvest within spatial blocks encompassing the outer banks for both recreational and commercial fishers and compared these amounts to the other blocks in the SCB. We assessed linear trends in commercial catch over time using simple linear regression. All data were analyzed using R version 3.3.1 (R Core Team 2016).

\section{RESUlTS}

Recreational fishers target benthic and pelagic taxa on the banks, and these taxa are reported as the number of individuals caught (Appendix 1); the numbers caught within each of 19 fishing blocks from 1980 to 2009 are reported in Table 1. The most numerous group was the rockfishes (Sebastes spp.) repre- senting $56.8 \%$ of the reported catch. Two species of rockfish, the Cowcod and Boccacio (S. levis and S. paucispinis) were individually reported while the rest of the species within the genus were recorded together. Rounding out the top 3 taxa are Albacore Tuna (Thunnus alalunga) and Ocean Whitefish (Caulolatilus princeps). Catches of 11,543 Kelp Bass (Paralabrax clathratus), a shallow reef species, were also reported. Pacific Bonito (Sarda chiliensis), California Sheephead (Semicossyphus pulcher), and Yellowtail (Seriola lalandi) represent $12.7 \%$ of the reported catch (ranks 4-6). Other important species are California Scorpionfish (Scorpaena guttata), Yellowfin Tuna (Thunnus albacares), Pacific Mackerel (Scomber japonicus), Bluefin Tuna (Thunnus thynnus), California Barracuda (Sphyraena argentea), and Skipjack (Katsuwonus pelamis). Of the remaining taxa, California spiny lobsters (Panulirus interruptus; $n=15,882$ ) and rock scallops (Crassadoma gigantea; $n=683$ ) were undoubtedly taken by scuba divers. Thus, the recreational fishers were targeting pelagic taxa (tunas and tunalike fishes), deep reef taxa (e.g., rockfishes, Lingcod, Ocean Whitefish), and shallow reef taxa (e.g., California Sheephead, Kelp Bass, California spiny lobster; Fig. 2, Table 2).

Commercial fishers report their landings using the same fishing blocks, but catches are reported by weight. Of identified taxa, 27,765 metric tons representing 129 taxa were reported taken from the banks during this period (Appendix 2). The greater diversity is because of the multiple types of fishing gear employed (purse seines, hook and line, traps, trawls, longlines, gill nets, etc.), plus many of the rockfishes (Sebastes spp.) were recorded by species. The top $96.8 \%$ of the catch, comprising 25 taxonomic categories, is reported in Table 3. Commercial fishers targeted wetfish such as Jack Mackerel (Trachurus symmetricus), Chub Mackerel (Scomber japonicus), Northern Anchovy (Engraulis mordax), Pacific Sardine (Sardinops sagax), and market squid (Doryteuthis opalescens), reporting 6295 metric tons caught. The wetfish landed from this region, however, are only a small fraction $(<0.01 \%)$ of the catch over the whole bight (Appendix 2). Because purse seines typically catch these species in high volume, a single catch can skew the analysis. Other important pelagic species (Common Thresher [Alopias vulpinus], White Seabass [Atractoscion nobilis], Opah [Lampris 


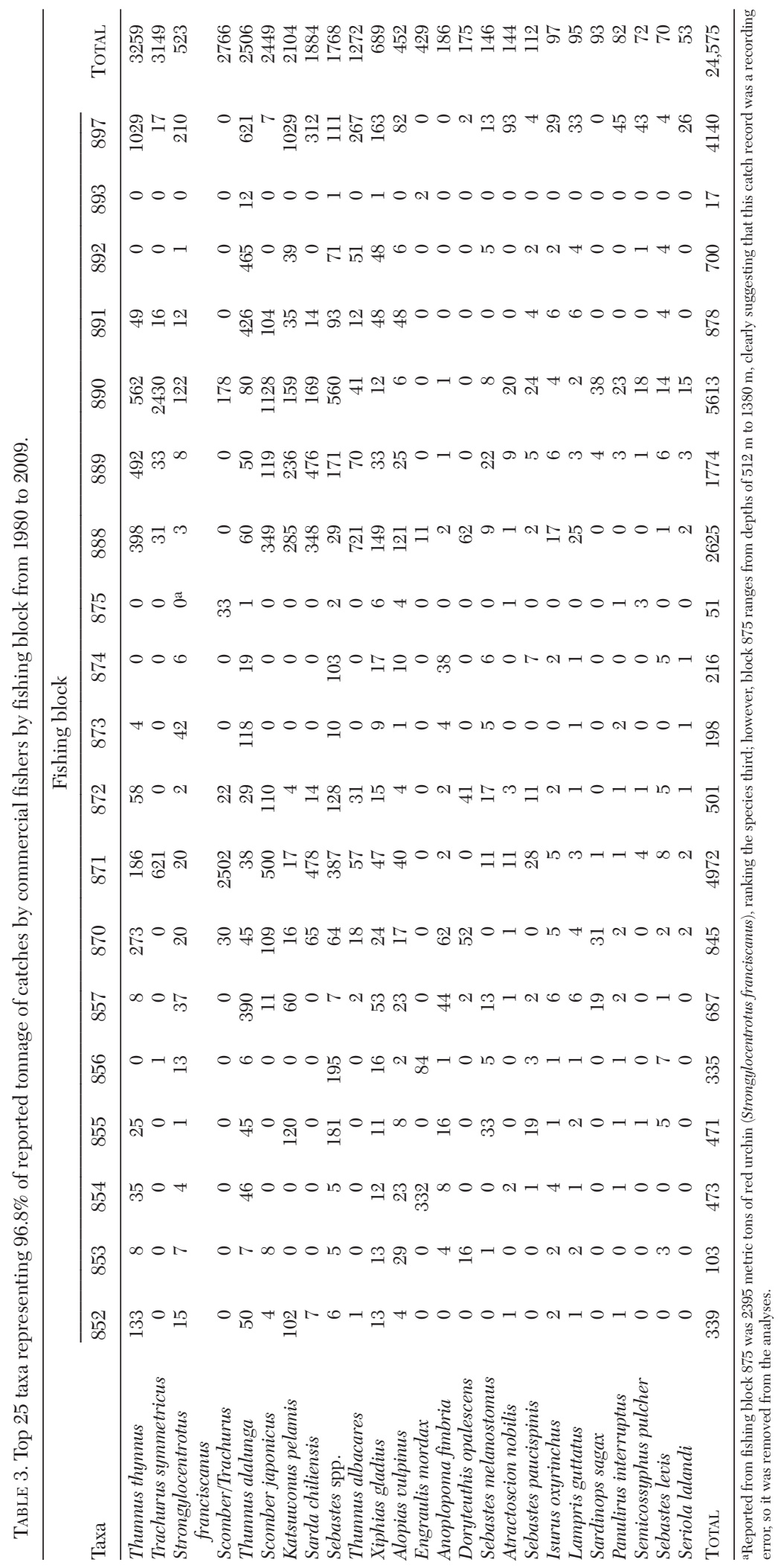



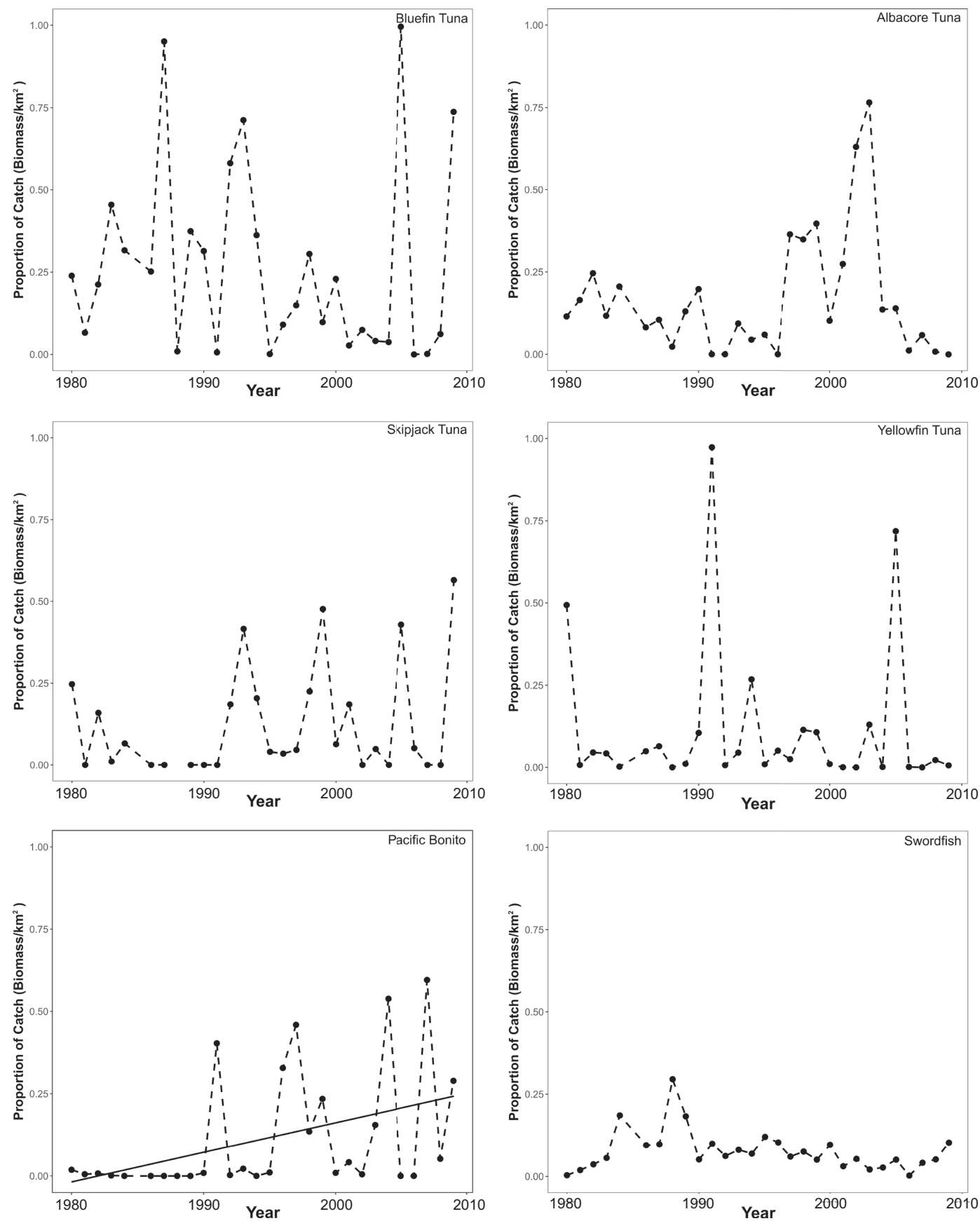

Fig. 3. Proportion of Bluefin Tuna, Albacore Tuna, Skipjack Tuna, Yellowfin Tuna, Pacific Bonito, and Swordfish caught at the Southern California offshore banks. Proportions are relative to the entire catch of the Southern California Bight. There was a significant increase in Pacific Bonito catch over time (Table 2).

guttatus], Shortfin Mako [Isurus oxyrinchus], and Bigeye Tuna [Thunnus obesus]) were also routinely caught in this region (11.5 metric tons).
The overall composition of the take was not consistent in the recreational fishery (Fig. 2, Table 2). Excluding wetfish, these fisheries 
TABLE 4. Mean proportion and 95\% CI of commercial catch from 1980 to 2009 at the Southern California offshore banks relative to the entire catch of the Southern California Bight for the individual and combined catch of various tunas and swordfish. Regression analysis (linear trend in catch over time; Fig. 3) statistics are also reported.

\begin{tabular}{|c|c|c|c|c|c|c|}
\hline Taxa & $\begin{array}{c}\text { Mean } \\
\text { proportion }\end{array}$ & $95 \% \mathrm{CI}$ & $\begin{array}{l}\text { Regression } \\
\text { slope }\end{array}$ & $95 \% \mathrm{CI}$ & $P$ & Adjusted $\mathrm{R}^{2}$ \\
\hline Bluefin Tuna & 0.27 & 0.16 to 0.37 & -0.003 & -0.016 to 0.010 & 0.61 & 0.03 \\
\hline Albacore Tuna & 0.17 & 0.10 to 0.24 & 0.002 & -0.006 to 0.011 & 0.51 & 0.02 \\
\hline Skipjack Tuna & 0.12 & 0.59 to 0.19 & 0.004 & -0.003 to 0.012 & 0.25 & 0.013 \\
\hline Yellowfin Tuna & 0.11 & 0.03 to 0.20 & -0.002 & -0.012 to 0.008 & 0.69 & 0.03 \\
\hline Pacific Bonito & 0.11 & 0.05 to 0.18 & 0.009 & 0.002 to 0.016 & 0.02 & 0.15 \\
\hline Swordfish & 0.08 & 0.05 to 0.10 & -0.002 & -0.004 to 0.001 & 0.19 & 0.03 \\
\hline
\end{tabular}

focused on 6 high-value pelagic taxa. These included the scombrids (Bluefin Tuna, Albacore, Skipjack, Yellowfin Tuna, and Bonito) and Swordfish (Xiphiidae). Relatively high percentages of the entire catch of these 6 taxa were caught at the offshore banks. In multiple years, $75 \%-100 \%$ of the Bluefin Tuna, Yellowfin Tuna, and Albacore caught in Southern California were reported from this region (Fig. 3). During the study period (1980-2009) there was a significant increase in Pacific Bonito catch (Table 4, Fig. 3) and relatively higher catches of Albacore and Skipjack Tuna in the 1990s and 2000s (Fig. 3). The increase in Albacore and Skipjack Tuna, however, was not significant (Table 4). The mean percentage of these species caught during the study period (1980-2009) at the offshore banks relative to the rest of the SCB ranged from $8 \%$ (Swordfish) to $27 \%$ (Bluefin Tuna), with $16 \%$, on average, of all species being caught at the offshore banks (Table 4). The majority of the catch was from Cortes and Tanner Banks (fishing blocks 870-872, 888-890, and 897) representing $3.7 \%\left(2603 \mathrm{~km}^{2}\right.$ of $\left.69,913 \mathrm{~km}^{2}\right)$ of the fishing grounds in the SCB.

\section{DisCUSSION}

Due to physical oceanographic patterns and geology, the Southern California offshore banks are the template for a unique environment. These seamounts and banks are bathed in the productive forces of the California Current and the Southern California Countercurrent and spatially provide a large proportion of the subtidal habitat in the bight (Emery 1960, Hickey 1992, Pondella et al. 2015). This subtidal habitat supports critical benthic resources, including the giant kelp (Macrocystis pyrifera) community, deeper hydrocoral (Stylaster californicus) communities, and deep coral habitats
(Lewbel et al. 1981, Lissner and Dorsey 1986, Etnoyer and Morgan 2003, Yoklavich et al. 2013). The productivity and the uniqueness of these habitats support a vibrant ecosystem including marine birds, mammals, fishes, and invertebrates that are utilizing both benthic and pelagic resources (Butler et al. 2006, Oleson et al. 2007, Love et al. 2010, Maxwell et al. 2012, Douglas et al. 2014). It is therefore not surprising that the Southern California offshore banks are extensively accessed by recreational and commercial fishers.

Recreational fishers targeted pelagic and coastal pelagic taxa, primarily catching Albacore, Yellowtail, Pacific Bonito, Yellowfin Tuna, and Bluefin Tuna. However, benthic taxa dominated the catch numerically, with a focus on Rockfish, Ocean Whitefish, California Sheephead, Spiny Lobster, and Kelp Bass. Sportfishers typically target high-value pelagics at these offshore areas, but the greater landing numbers of benthic fishes indicate their availability; considering the distance from port (Zellmer et al. 2018), these taxa were likely targeted as alternatives when pelagic species were not being caught. Critical populations of Cowcod and Boccacio were historically targeted in this region by both commercial and recreational fishers (Butler et al. 2003, Yoklavich et al. 2007). Dive charters were also a significant component of these landings. Benthic resources such as spiny lobster and rock scallops, which can only be taken by divers, were clear indications of utilization by this sector. The bulk of the recreational fishery in Southern California is based on the mainland due to the proximity to port (Zellmer et al. 2018). Thus, the recreational catch at these banks and seamounts is comparatively low to the mainland catch, although multiday charters to this region represent a high commercial value to the local industry. 
The utilization of this region by commercial fishers was more dramatic. Commercial fishers successfully targeted high-value pelagic fisheries with relatively lower take of benthic resources (Table 3). It should be noted that the Cowcod Conservation Area has limited the catch of benthic resources at a depth $>20$ fathoms (36.6 m) since 2001. The other significant fishery regulation change was the closure of the abalone (Haliotis spp.) fishery in 1997.

\section{Conclusion}

Based upon our review of the biological and physical data, the outer banks represent a unique set of habitats in the SCB. These environs support high-value recreational and commercial fishing interests. Specifically, this area is critical for commercial fisheries where pelagics (e.g., Bluefin Tuna, Albacore, Skipjack, Yellowfin Tuna, Pacific Bonito, Swordfish) were the most important taxa and represented a substantial proportion of the landings of these commercial pelagic fishes in the SCB. When comparing the surface area of fishable habitat relative to the rest of the bight, a disproportionate amount of these pelagic taxa were landed at Cortes and Tanner Banks. Because of their geography, physical oceanography, biology, and landings from recreational and commercial fisheries, these offshore banks compose a unique habitat in the region.

\section{Literature Cited}

Allen, L.G., And M.H. HoRn. 1978. A distributional analysis of California coastal marine fishes. Journal of Biogeography 5:23-42.

Auad, G., D. Roemmich, and J. Gilson. 2011. The California Current system in relation to the northeast Pacific Ocean circulation. Progress in Oceanography 91:576-592.

Bray, N.A., A. Keyes, and W.M.L. Morawitz. 1999. The California Current system in the Southern California Bight and the Santa Barbara Channel. Journal of Geophysical Research-Oceans 104:7695-7714.

Butler, J.L., L.D. Jacobson, T.J. Barnes, and H.G. Moser. 2003. Biology and population dynamics of cowcod (Sebastes levis) in the Southern California Bight. Fishery Bulletin 101:260-280.

Butler, J.L., M.J. Neuman, D. Pinkard, R. Kvitek, and G. Cochrane. 2006. The use of multibeam sonar mapping techniques to refine population estimates of the endangered white abalone (Haliotis sorenseni). Fishery Bulletin 104:521-532.

Crouch, J.K., AND J. Suppe. 1993. Late Cenozoic tectonic evolution of the Los Angeles basin and inner California borderland: a model for core complex-like crustal extension. Geological Society of America Bulletin 105:1415-1434.
Dong, C., E.Y. Idica, and J.C. McWilliams. 2009. Circulation and multiple-scale variability in the Southern California Bight. Progress in Oceanography 82: $168-190$.

Douglas, A.B., J. Calambokidis, L.M. Munger, M.S. Soldevilla, M.C. Ferguson, A.M. Havron, D.L. Camacho, G.S. Campbell, and J.A. Hildebrand. 2014. Seasonal distribution and abundance of cetaceans off southern California estimated from CalCOFI cruise data from 2004 to 2008. Fishery Bulletin 112:198-220.

EmerY, K.O. 1960. The sea off Southern California. John Wiley \& Sons, Inc., New York, NY.

Etnoyer, P., and L. Morgan. 2003. Occurrences of habitat-forming deep sea corals in the northeast Pacific Ocean: a report to NOAA 's Office of Habitat Conservation. Marine Conservation Biology Institute, Redmond, WA. 33 pp. https://www.pcouncil .org//bb/2004/0304/G2a_Att1_Mar04_BB.pdf

Gautam, A., M. Holliday, AND R. Lent, editors. 1996. Our living oceans: the economic status of U.S. fisheries. NOAA-NMFS, Fisheries Statistics Division.

Genin, A., and G.W. Boehlert. 1985. Dynamics of temperature and chlorophyll structures above a seamount: an oceanic experiment. Journal of Marine Research 43:907-924.

Hickey, B.M. 1992. Circulation over the Santa MonicaSan Pedro basin and shelf. Progress in Oceanography 30:37-115.

Hill, K.H., AND N. SCHNEIDER. 1999. Historical logbook databases from California's commercial passenger fishing vessel (partyboat) fishery, 1936-1997. Series No. 99-19. Scripps Institution of Oceanography/ University of California, San Diego, CA. 65 pp.

Kildow, J., and C.S. Colgan. 2005. Report to the Resources Agency, State of California. Prepared by The National Ocean Economics Program. 156 pp.

Lekic, V., S.W. French, AND K.M. Fischer. 2011. Lithosperic thinning beneath rifted regions of Southern California. Science 334:783-787.

Lewbel, G.S., A. Wolfson, T. Gerrodette, W.H. LipPINCOTT, J.L. Wilson, AND M.N. LitTleR. 1981. Shallow-water benthic communities on California's outer continental shelf. Marine Ecology Progress Series 4:159-168.

Lissner, A.L., AND J.H. Dorsey. 1986. Deep-water biological assemblages of a hard-bottom bank-ridge complex of the southern California continental borderland. Bulletin of the Southern California Academy of Sciences 85:87-101.

Love, M.S., B. Lenarz, and L. SNOOK. 2010. A survey of the reef fishes, purple hydrocoral (Stylaster californicus), and marine debris of Farnsworth Bank, Santa Catalina Island. Bulletin of Marine Science 86:35-52.

Love, M.S., M. Yoklavich, and D.M. Schroeder. 2009. Demersal fish assemblages in the Southern California Bight based on visual surveys in deep water. Environmental Biology of Fishes 84:55-68.

Maxwell, S.M., J.J. Frank, G.A. Breed, P.W. Robinson, S.E. Simmons, D.E. Crocker, J.P. Gallo-Reynoso, AND D.P. Costa. 2012. Benthic foraging on seamounts: a specialized foraging behavior in a deepdiving pinniped. Marine Mammal Science 28:1-12.

Oleson, E.M., S.M. Wiggins, and J.A. Hildebrand. 2007. Temporal separation of blue whale call types on a southern California feeding ground. Animal Behavior 74:881-894. 
Pendleton, L.H., And J. Rooke. 2006. Understanding the potential economic impact of marine recreational fishing: California. Report to the Santa Monica Bay Restoration Commission. 19 pp. https://www.dfg.ca .gov/marine/pdfs/binder3di.pdf

Perry, W., K. Gustafsson, G. Sanders, and J. Takekawa. 2010. Pacific Coast Fisheries GIS Resource Database [CD-ROM]. U.S. Geological Survey, Western Ecological Research Center, Dixon and Vallejo, CA; and Bureau of Ocean Energy Management, Regulation and Enforcement, Camarillo, CA. BOEMRE Study Profile \#2010-023.

Pondella, D.J., J. Williams, J. Claisse, R. Schaffner, K. Ritter, And K. Schiff. 2015. The physical characteristics of nearshore rocky reefs in the Southern California Bight. Bulletin of the Southern California Academy of Sciences 114(3):105-122.

Pondella, D.J., II, B.E. Gintert, J.R. CobB, and L.G. ALLEN. 2005. Biogeography of the nearshore rockyreef fishes at the southern and Baja California islands. Journal of Biogeography 32:187-201.

R Core Team. 2016. R: a language and environment for statistical computing. R Foundation for Statistical Computing, Vienna, Austria. https://www.R-project .org
Yoklavich, M., T. Laidig, A. Taylor, D. Watters, L. Krigsman, AND M. Love. 2013. A characterization of the Christmas tree black coral (Antipathes dendrochristos) community on three seamounts in the Southern California Bight from a survey using a manned submersible. A report to NOAA Deep-sea Coral Research and Technology Program. http:// swfsc.noaa.gov/publications/CR/2013/2013Yoklavich2 .pdf

YoKlavich, M., M.S. Love, and K.A. Forney. 2007. A fishery-independent assessment of an overfished rockfish stock, cowcod (Sebastes levis), using direct observations from an occupied submersible. Canadian Journal of Fisheries and Aquatic Sciences 64:1795-1804.

Zellmer, A.J., J.T. Claisse, C.M. Williams, and D.J. PONDELLA. 2018. Long-term, spatial marine harvest intensity as an indicator of human impact on shallow rocky reef ecosystems. Marine Ecology. https://doi .org/10.1111/maec.12463

Received 2 March 2017 Revised 7 November 2017 Accepted 13 November 2017 Published online 19 September 2018 


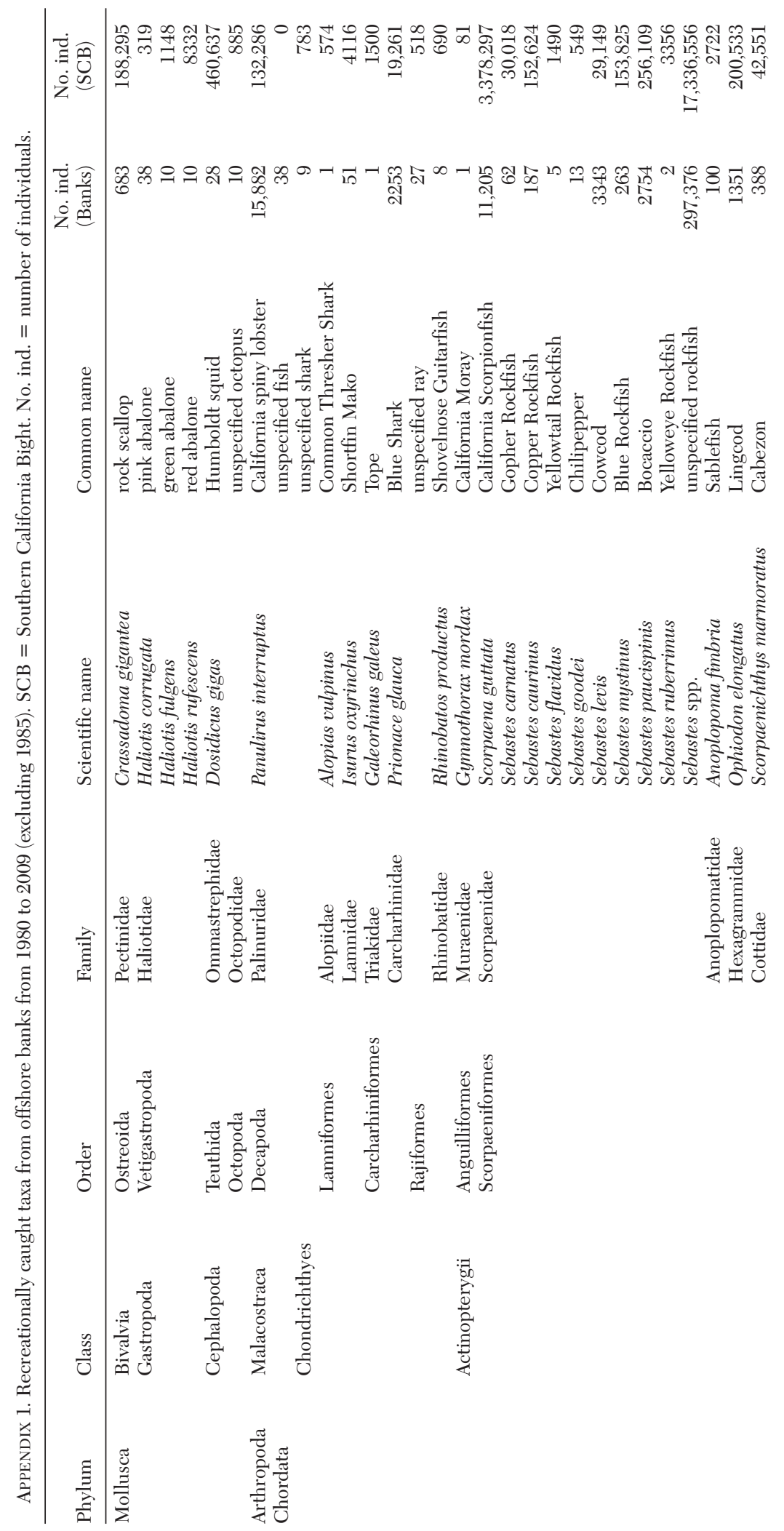




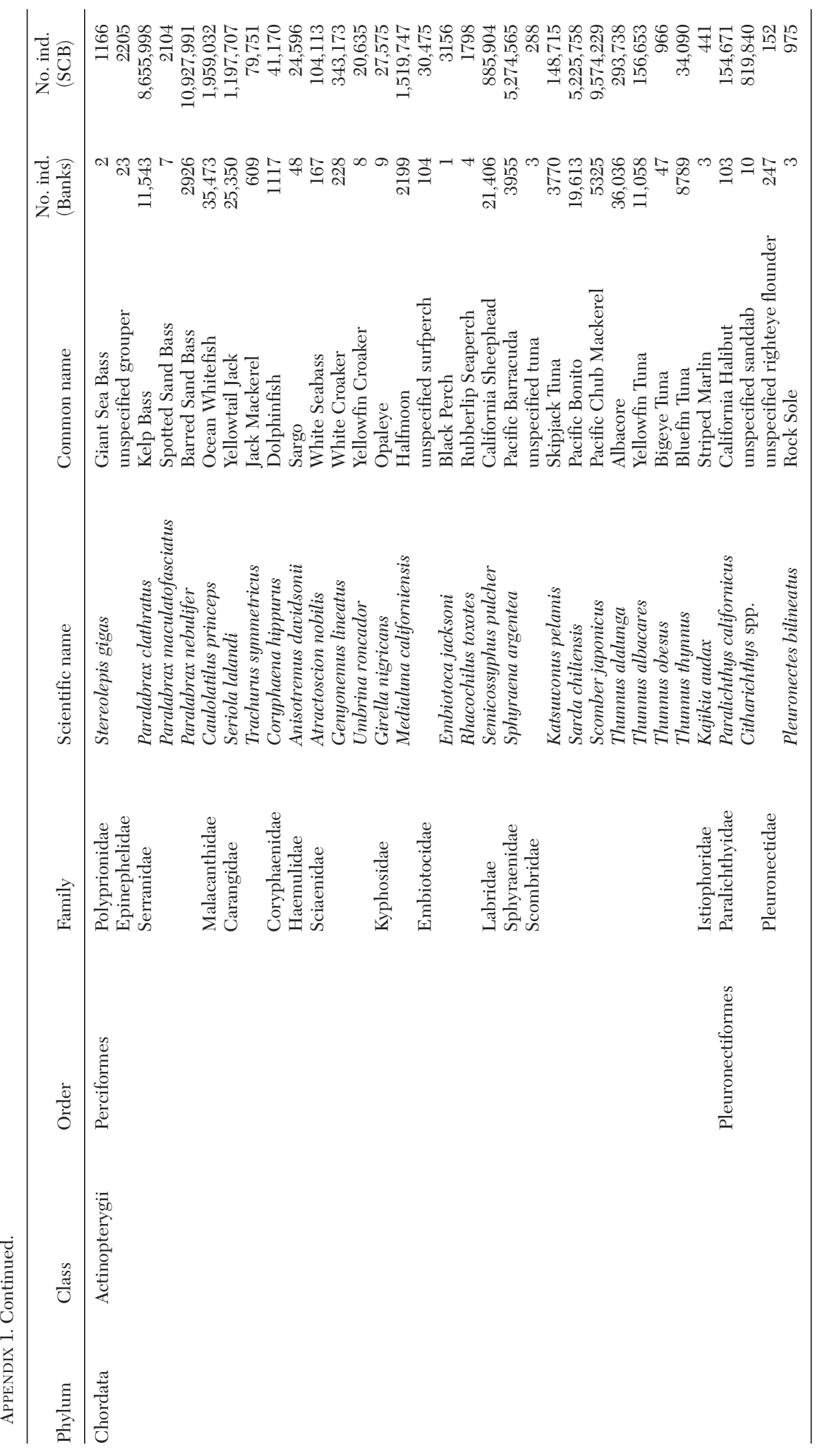




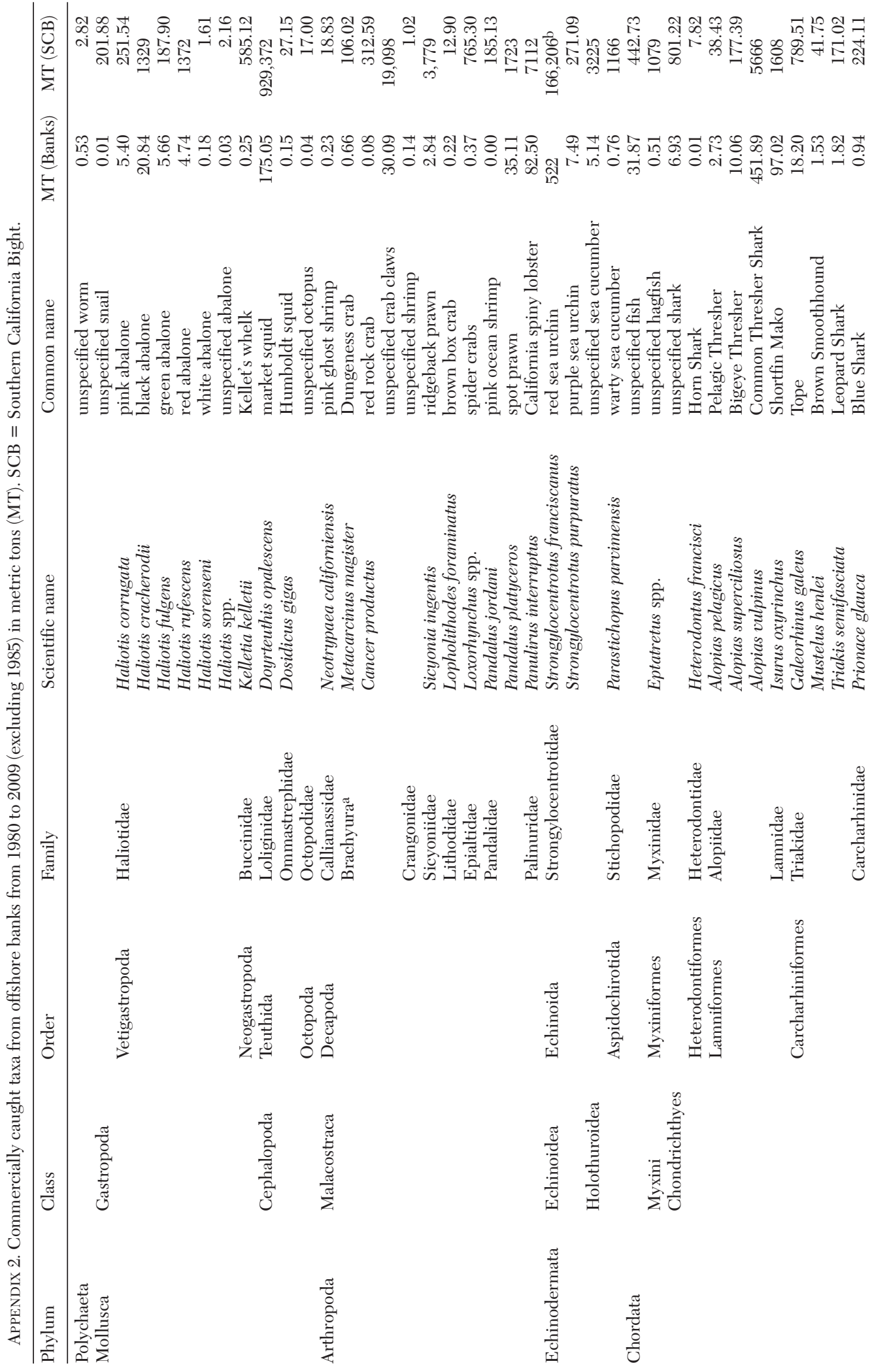




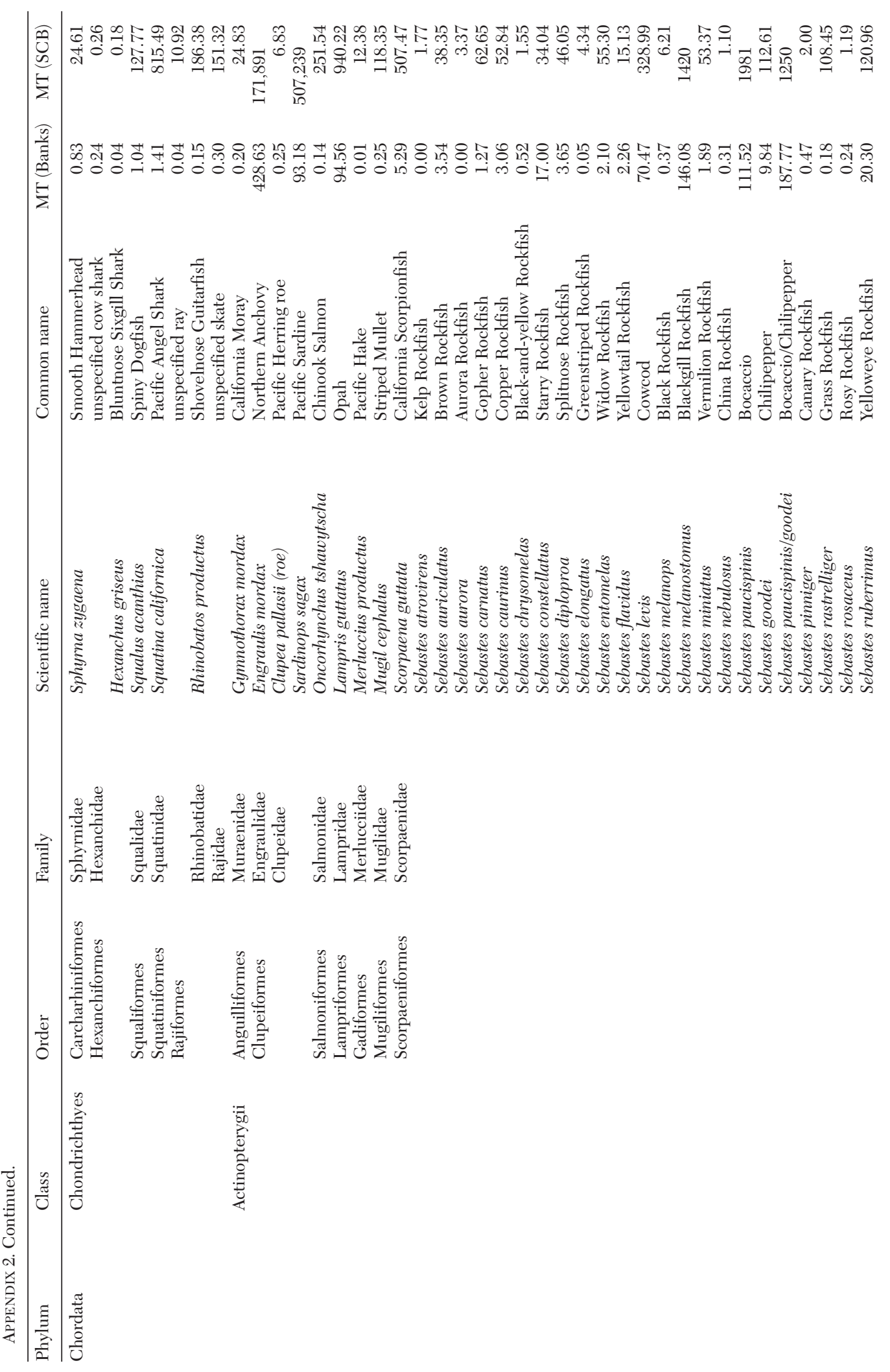




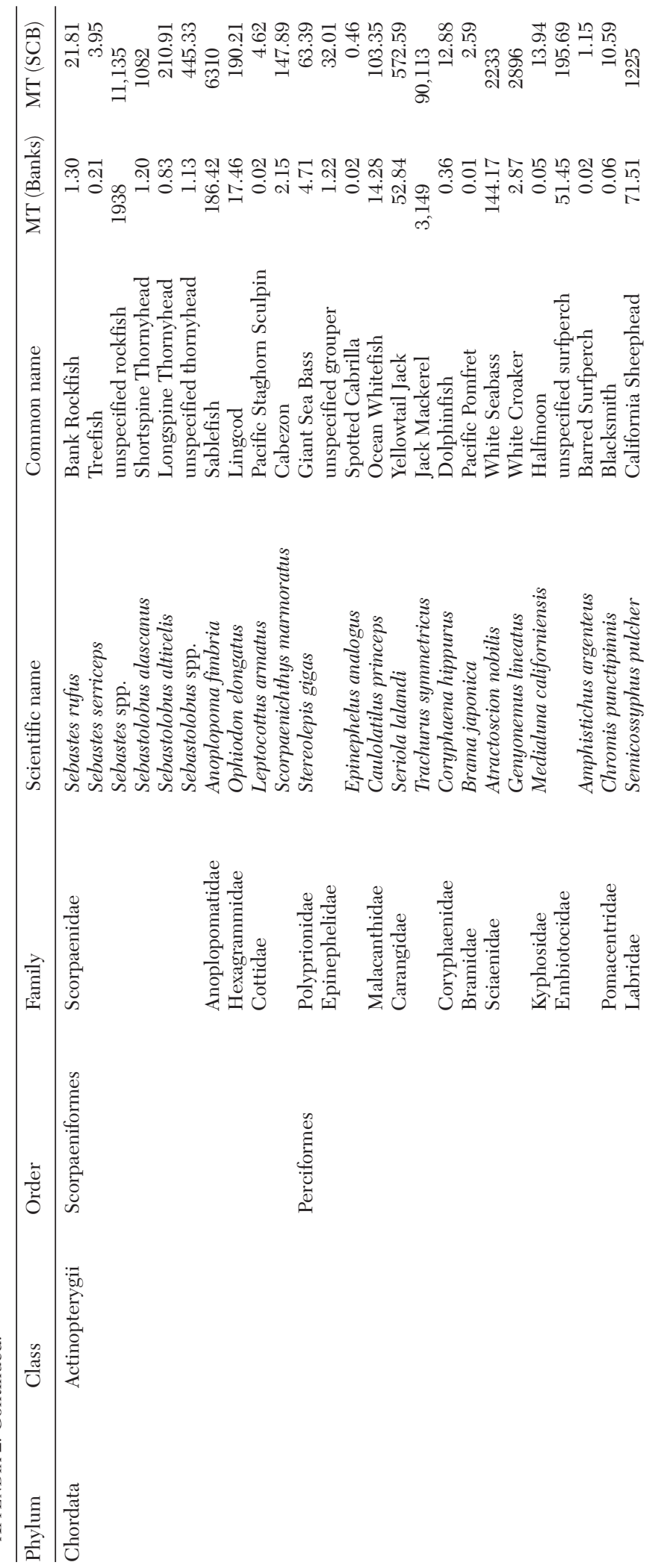




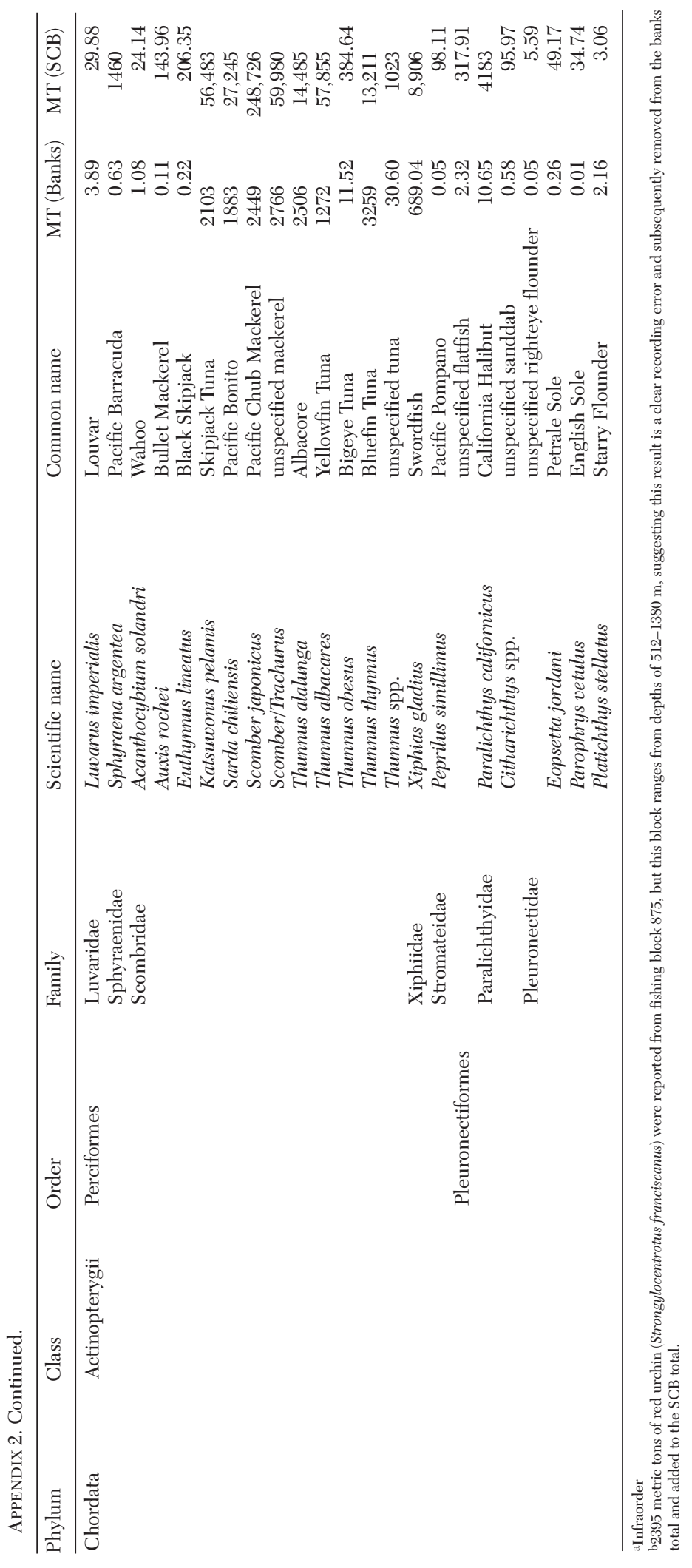

